\title{
Hermeneutiikka ja fenomenologia
}

\section{Hermeneuttis-fenomenologisen tutkimusotteen}

\section{sisäisestä problematiikasta}

\author{
LEENA KAKKORI
}

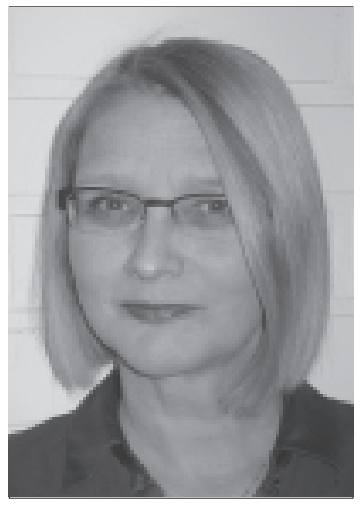

\begin{abstract}
"Hermeuttis-fenomenologinen tutkimusote on löytänyt tiensä myös aikuiskasvatustieteelliseen tutkimukseen. Se ei kuitenkaan ole selkiinnyttänyt periaatteitaan, vaikka sen tulokset avaavat uusia näköalaoja. Hermeneutiikka ja fenomenologia ovat molemmat filosofisia suuntauksia, joilla on oma perinteensä ja lähtökohtansa. Niiden historiassa löytyy yhtymäkohtia, mutta ne eivät ole suoraan yhteen sovitettavissa yleiseksi metodiksi. Nillä on jopa perustavaa laatua olevia eroja”, väittää näkökulman kirjoittaja.
\end{abstract}

$\mathrm{H}$ ermeneuttis-fenomenologinen tutkimusote tai metodi löytyy nykyään monen humanistisen ihmistieteen tutkimussuunnitelman ja tutkimuskuvauksen alusta. Erityisesti kasvatustiede ja hoitotiede ovat ottaneet tutkimusmetodin omakseen. Pohjoismaissa metodi on laajasti käytössä ja yksi tunnetuin sen edustajista on Max van Manen. Hermeneuttis-fenomenologinen tutkimusote jää kuitenkin useasti heikosti määritellyksi ja moniselitteiseksi. Tämä johtuu tutkimusotteen sisäisestä ristiriitaisuudesta, koska siinä on yhdistetty kaksi erilaista filosofista ajattelusuuntaa, joilla kummallakin on oma historiansa. Hermeneutiikka suuntautuu historiallisiin ja tulkinnassa muuttuviin merkityksiin husserlilaisen fenomenologian pyrkiessä universaaleihin ja absoluuttisiin olemuksiin. Martin Heidegger yhdistää fenomenologian ja hermeneutiikan omassa filosofiassaan erityisellä tavalla. Hänelle hermeneuttinen fenomenologia on olemisen merkityksen tutkimusta fundamentaalisena ontologiana. Hermeneuttinen fenomenologia tässä merkityksessä ei kuitenkaan ole käyttökelpoinen laadullisessa tutkimuksessa.
Fenomenologia määritellään yleisellä tasolla tutkimukseksi ilmiöiden olemuksista ja hermeneutiikka tulkinnan opiksi. Näin määriteltynä fenomenologia ja hermeneutiikka eroavat toisistaan perustavanlaatuisesti.

Fenomenologian varsinaisena isänä ja perustajan voidaan pitää filosofi Edmund Husserlia (1859-1938). Hans-Georg Gadamer (1900 2002) taasen tunnetaan filosofisen hermeneutiikan perustajana. Martin Heidegger asettuu näiden kahden saksalaisen filosofin väliin, ollen Husserlin oppilas ja Gadamerin opettaja. Näiden kolmen edustamat ja kehittämät filosofiat eivät kuitenkaan ole nähtävissä yhtenäisenä jatkumona toisesta toiseen, vaan jokainen edustaa omaa filosofista ajattelutapaa. Heidän filosofioillaan on tietenkin yhtymäkohtia ja he ovat saaneet vaikutteita toinen toisistaan, filosofiset lopputulokset ovat kuitenkin hyvin erilaiset.

On myös monia muita merkittäviä hermeneutikkoja kuin fenomenologejakin. Tässä yhteydessä voin mainita Maurice Merleau-Pontyn (2006). Hänen merkittävin väitteensä kuuluu siten, että me 
olemme ennen kaikkea kehomme tai ruumiimme ja elämyksemme tästä kehosta kieltää objektin erottamisen subjektista.

1970- ja 1980-luvuilla Amadeo Giorgi (1982), Donald Polkinghorne (1976) ja Max van Manen (1084, 1989; 1990) sekä eräät muut toivat laadullisen ja erityisesti fenomenologisen tutkimusmetodin psykologiaan ja kasvatustieteeseen. Heidän ehdottamansa fenomenologinen lähestymistapa empiirisen tutkimuksen alueelle ihmistieteissä oli suorastaan avantgardistista ja heidän ansionsa ovat kiistattomia. Max van Manen on yksi tunnetuimmista niin Suomessa kuin muualla pohjoismaissa sekä Englannissa ja Kanadassa. Van Manen ei ole tunnettu Saksassa, jossa on oma vahva fenomenologinen perinne kasvatustieteen parissa.

Van Manen tunnetaan erityisesti hänen eletty elämys/kokemus -käsitteestään (lived experience), joka kuuluu hänen kehittelemäänsä hermeneuttisfenomenologiseen tutkimusmetodiin. Olen van Manenin kanssa samaa mieltä siitä, ettei jokaisen kasvatustieteilijän tai tutkijan tarvitse olla filosofi, vaikka käyttävätkin filosofisesti mutkikkaalta kuulostavaa fenomenologis-hermeneutissa metodia (Manen 1990, 7-8). Oli sitten filosofi tai ei, on tiedettävä, mitä tällä metodilla tarkoitetaan, koska muuten ollaan vakavissa vaikeuksissa itse laadullisen tutkimuksen arvovaltaa ja pätevyyttä koskevissa keskusteluissa. Erityisesti siksi olisi tiedettävä, mitä tekee, kun käyttää kyseistä metodia määrittelemään tutkimustaan, koska väitteeni mukaan hermeneutiikka ja fenomenologia ovat tietyissä asioissa perustavanlaatuisesti keskenään ristiriitaisia ja vastakkainasettuvia filosofisia suuntauksia.

Kun nämä käsitteet sitten yhdistetään, täytyy tietää, mitä tekee. Näkökulma-artikkelin tarkoituksena on tuoda tätä problematiikkaa ja jännitettä esiin. Jännite, mikä hermeneutiikan ja fenomenologian välillä on, voidaan lyhyesti kuvata seuraavasti: fenomenologian päämääränä ja pyrkimyksenä on löytää asioiden olemus, kun taas hermeneutiikan mukaan asiat ovat mitä ovat kielen ja tulkinnan kautta.

\section{Mitä on fenomenologia?}

$\mathrm{K}$ ysymykseen, mitä on fenomenologia, voi yrittää lähteä vastaamaan kahdella tavalla. Yksi tapa on kääntyä niin sanotun fenomenologisen liikkeen puoleen (Spiegelberg 1982). Vaikeutena tässä on se, että filosofian historiassa fenomenologiaa on käytetty hyvin erilaisissa merkityksissä. Kuuluisin filosofien parissa on Hegelin hengen fenomenologia, Phänomenologie des Geistes. Hegel ei kuitenkaan auta millään tavalla ymmärtämään modernia fenomenologiaa. Toinen tapa ymmärtää fenomenologia on pitää sitä omana filosofisena oppinaan, jolla on oma tutkimuksenalansa, nimittäin tietoisuus tai kokemus. Modernin fenomenologian oppi-isänä voidaan pitää Edmund Husserlia.

Fenomenologian tehtävä oli Husserlille antaa uusi perusta niin tieteelle kuin filosofiallekin. Hän kehitti fenomenologian käsitettään vähitellen ja muotoillen sitä uudelleen koko elämänsä ajan. Häneltä on löydettävissä erilaisia fenomenologian määritelmiä ja muotoja deskriptiivisestä fenomenologiasta geneettiseen ja transsendentaaliseen fenomenologiaan. Yleisesti kuvaten husserlilaista fenomenologiaa voisi sanoa, että se on filosofian tutkimussuuntaus ja oppi, joka pyrkii tutkimaan tietoisuuden rakenteita havaintokokemuksessa.

Husserl piti merkittävämpänä saavutuksenaan reduktiota eli niin sanottua sulkeistamista. Hän piti reduktiota hyvin komplisoituna ja problemaattisena asiana fenomenologiassa ja kehitti käsitettä jatkuvasti. Husserlin kuuluisan sloganin mukaan meidän on palattava "asioihin itseensä", "Zu den Sachen selbst". Slogan viittaa Husserlin pyrkimykseen ottaa uusi lähestymistapa konkreetisti koettuun ilmiöön, lähestymistapa, joka on mahdollisimman vapaa käsitteellisistä ennakkoluuloista ja asenteista.

Husserlin pyrkimys oli saattaa loppuunsa filosofian uudistaminen tieteeksi, joka perustuu absoluuttiselle perustalle (Husserl 1999, 1). Husser julistaa: "Me olemme tosi positivisteja". (Husserl 1992, 38.) Fenomenologian päämäärä sai selkeän muotoilun ensimmäisen kerran Husserlin Logoslehden artikkelissa Philosophie als strenge Wissenschaft (1965), jossa hän käsittelee kahta näkemystä, joita ei voi hyväksyä, nimittäin historismia ja naturalismia.

Reduktio on fenomenologinen väline, joka pitää olla hallussa, ennen kuin voidaan tehdä Husserlin tarkoittamaa fenomenologiaa. Yksinkertaistettuna ja tiivistettynä reduktio tarkoittaa muutosta tavallisesta yksinkertaisesta asenteesta eli luonnollisesta asenteesta maailman ja siinä kohdattavien objektien suhteen reflektiiviseen asenteeseen. Husserl pyrki löytämään puhtaan lähtökohdan tutkimukselleen samalla tavalla kuin Descartes, joka esitti, ettei voi olla mistään muusta varma kuin 
omasta olemassaolostaan. Samoin kuin Descartes, ei Husserlkaan epäillyt maailman olemassaolo. Hän kuitenkin halusi päästä irti kaikista ennakkoasetuksista ja sen vuoksi sulkeista maailman olemassaolon kääntyen tietoisuuteen ja siihen, miten asiat ilmenevät meille tietoisuudessa. Tosin sanoen, maailman olemassaolo sulkeistetaan. Reduktioista voidaan puhua kolmella tasolla, joita kaikkia voi kutsua fenomenologisiksi reduktioiksi. Erityisesti kuitenkin fenomenologisella reduktiolla tarkoitetaan enismmäistä maailman pois sulkeistavaa reduktiota. Tämä tarkoittaa sitä, että kaikki mitä kohtaamme tulevat ilmiöksi, jotka tiedetään ja kohdataan tietoisuudessa. Käännytään pois maailmasta siihen, mitä tietoisuudelle siirtyy. (Spiegelberg 1984, 119; Juntunen 75.)

Toinen reduktio on eideettinen reduktio, jossa tietoisuus erilaisten toimien kautta saavuttaa olemuksen eli eidoksen. Tässä vaiheessa tietoisuus muodostaa siitä moneudesta, mitä on annettu tietoisuudelle ykseyden. Ykseys on se, mikä on kohteessa muuttumatonta. Esimerkiksi, sen mikä tekee puusta puun, sen muuttumattoman puumaisuuden, puun eidoksen. (Juntunen 1986, 74-75.)

Kolmas reduktio on transsendentaalinen reduktio, jonka kautta meillä on pääsy niin sanottuun transsendentaaliseen egoon tai puhtaaseen tietoisuuteen, jolle kaikki mitä on, on objektina. Fenomenologian tehtäväksi tulee kuvata ja tutkia, miten tämä puhdas tietoisuus tosiasiallisesti toimii. Fenomenologia näin ollen tutkii ja kuvaa olevan aluetta, jolle ei yllä empiirinen tarkastelu, vaan ainoastaan fenomenologinen kuvaus. Tämä transsendentaalinen ego saa tietyissä kohdin Husserlin tuotantoa hyvinkin kummalliselta kuuluvia määritelmiä. Husserl esimerkiksi väittää, että transsendentaalinen ego olisi olemassa, vaikka koko maailma tuhoutuisi. (Juntunen 1986, 70-74; Natason 1973, 65-66.)

Reduktion lisäksi on käsiteltävä lyhyesti Husserlin käsitettä elämismaailma (Lebenswelt). Husserl otti käsitteen käyttöön keskeneräiseksi jääneessä teoksessaan Die Krisis der Europäischen Wissenschaften und die transzendentale Phänomenologie. Tätä käsitettä käytetään monissa fenomenologisissa ja useissa hermeneuttis-fenomenologisissa tutkimuksissa. Useat Husserlin seuraajista ovat ottaneet sen käyttöönsä kuten Merleau-Ponty ja Habermas, mutta käyttäen sitä hyvin eri merkityksessä. Käsite on erittäin kiinnostava mutta epäselvä. Husserlin fenomenologian päätehtävä oli tähän saakka ollut ylittää reflektiolla ja reduktioilla niin sanottu luonnollinen asenne, joka esti pääsemästä asioihin itseensä. Nyt kuitenkin kaiken lähtökohdaksi tulee elämismaailma (Derrida 2008, 141-143) Kysymys onkin, kuinka elämismaailma ja luonnollinen asenne suhtautuvat toisiinsa. Monet pitävätkin elämismaailman käsitettä sovittamattoman aikaisempaan Husserlin filosofiaan nähden. Elämismaailmalla tarkoitetaan yleisellä tasolla jonkinlaista suoraa ja välitöntä suhdetta maailmaan erotettuna tieteellisestä objektivoivasta suhteesta maailmaan. Määrittelyt kuitenkin yleensä jäävät tähän, jonka jälkeen lähdetään hakemaan apua viittaamalla milloin Husserliin, Heideggeriin tai Merleau-Pontyyn. Edessä on kuitenkin yleensä vaikeuksia, kuten jo edellä esitetty Husserlin filosofian lyhyt esittely näyttää. (Zahavi 2003 ja Carr 1981, xxxvii-hl.)

Husserlin oppilas Martin Heidegger ei käyttänyt elämismaailman käsitettä, vaan hän sen sijaan esitti fenomenologiansa olevan perustavalla tavalla hermeneutiikkaa. Heidegger painotti uudestaan ja uudestaan pitkin uraansa, kuinka tärkeä Husserlin filosofia hänelle oli. Olemisessa ja ajassa Heidegger kirjoittaa: "Seuraavat tutkimukset ovat tulleet mahdolliseksi vain Edmund Husserlin asettamalta perustalta" (Heidegger 2000, 62). Heideggerille fenomenologialla on vain yksi tehtävä: kysyä ja selvittää filosofian keskeisintä kysymistä, kysymystä olemisesta. Olemisessa ja ajassa Heidegger esittää ainoastaan valmistelevan selvityksen siitä, mitä fenomenologia on. Hänen mukaansa ymmärtäessämme fenomenologian olemiskysymyksen kontekstissa on se silloin ontologiaa. Sama väite on löydettävissä myös muualta: "Fenomenologia on nimi ontologian metodille." (Heidegger 1975, 27.)

Olemisessa ja ajassa Heidegger mukaan olemiskysyminen vaatii Daseinin, joka voidaan ymmärtää ihmisen erityisenä olemisen muotona. Dasein on onttis-ontologinen olento, jonka ansioista Daseinilla on kyky kysyä omaa olemistaan olevana. Tämä on heideggerilaisen hermeneutiikan ja fenomenologian ydintä. Hän näkee Daseinin fenomenologian olevan hermeneuttista perustavalaatuisessa mielessä. Teoksessaan Grundprobleme der Phänomenologie (1975) ei Heidegger selvitä paljoakaan enempää varsinaisesti sitä, mitä fenomenologia on. Hän ainoastaan esittää lyhyesti fenomenologisen tutkimuksen kolme peruselementtiä, jotka ovat reduktio, konstruktio ja destruktio.

Selvitän tässä nyt ainoastaan reduktion käsitettä, koska se on Husserlin keskeinen käsite. Hus- 
serlille fenomenologinen reduktio on menetelmä fenomenologisen näkökyvyn johtamiseksi tästä jokapäiväisestä ihmisten ja asioiden maailmasta eli luonnollisesta asenteesta - takaisin tietoisuuden transsendentaaliseen elämään ja kokemuksiin, joissa oliot konstituoidaan tietoisuuden korrelaatteina. Heideggerille fenomenologinen reduktio merkitsee fenomenologisen tarkastelun johtamista olevan ymmärtämisestä olevan olemisen ymmärtämiseen (Heidegger 1975, 29). Heideggerin pääargumentti on, että olemisen kysyminen on joko unohdettu kokonaan tai muutettu kysymykseksi olevasta entiteettinä. Heideggerille fenomenologinen reduktio tarkoittaa tarkastelun siirtämistä olevista olemiseen. Kaksi muuta mainittua fenomenologisen metodin osatekijää, destruktio ja konstruktio, palvelevat molemmat omalla tavallaan olemisen kysymistä.

\section{Mitä on hermeneutiikka?}

$\mathrm{H}_{\mathrm{e}}$ ermeneutiikalla on ainakin yhtä pitkä historia kuin fenomenologialle. Yleinen hermeneutiikan määritelmä on, että hermeneutiikka on tulkitsemista. Nykyään voimme löytää erilaisia hermeneutiikan määritelmiä Raamatun eksegetiikasta aina radikaaliin hermeneutiikkaan. Modernista hermeneutiikasta on löydettävissä kuusi erilaista määritelmää, jotka voidaan esittää myös hermeneutiikan historiallisina vaiheina. Näitä ovat (Palmer 1969,33):

1. Raamatun eksegetiikan teoria

2. Yleinen filologinen metodologia

3. Lingvistiikka, lingvistinen ymmärtäminen

4. Ihmistieteiden (Geisteswissenschaffenin) metodologinen perusta

5. Olemassaolon fenomenologia ja eksistentialistinen ymmärrys

6. Tulkinnan teoria, jolla pyritään myyttien ja symbolien taakse.

Nämä eivät ole ainoastaan historiallisia vaiheita, vaan myös osittain käytössä olevia määrityksiä, joilla on erilainen lähtökohta ja lähestymistapa hermeneutiikkaan.

Hermeneutiikka on yleisimmin ja pisimpään tunnettu pyhien tekstien kuten Uuden ja Vanhan Testamentin, Talmudin ja Koraanin eksegetiikkana, joka sai alkunsa 1700-luvulla. Eksegeesi teknisenä terminä tarkoittaa "merkityksen ulos vetämistä" annetusta tekstistä. Eksegeesin vastakohtana voidaan nähdä eisegeesi, (kreik. eisegesis), joka tar- koittaa subjektiivista oman tulkinnan lukemista mukaan tekstiin. Hermeneutiikka eksegeesinä tarkoittaa tekniikka, jonka avulla saavutamme objektiivisesti sen merkityksen, mitä kirjoittaja todella on tarkoittanut. Raamatun eksegetiikassa pyritään löytämään oikea tulkinta sille, mitä kirjoittajat ovat tarkoittaneet Jumalan sanana.

Hermeneutiikan toiseen vaiheeseen kuuluvat filologit Friedrich August Wolf (1759-1824) ja Friedrich Ast (1778-1841). He laajensivat hermeneutiikan koskemaan Raamatun eksegetiikasta koskemaan myös muita tekstejä. Astilta löytyy tiettyjä hermeneutiikan peruskäsitteitä ja ideoita, kuten hermeneuttinne kehä ja osan suhteen kokonaisuuteen. Wolf puolestaan painotti historiallisen tiedon merkitystä ja sitä, että tulkitsijalla pitäisi olla mahdollisemman paljon historiallista tietoa. Hän näki myös, että hermeneuttiseen tulkintaan kuuluu kaksi osatekijää: ymmärtäminen (verstehen) ja selittäminen (erklaren). (Palmer 1969, 78-82.)

Friedrich Schleiermacher edustaa lingvistisen ymmärtämisen vaihetta hermeneutiikassa. Schleiermacher puhuu yleisestä hermeneutiikasta (allgemeine Hermeneutik), jonka periaatteita voidaan soveltaa kaikkeen kielelliseen tulkintaan. Hänelle hermeneutiikka on ymmärtämisen taitoa, joka on luonteeltaan dialogista kuulijan ja puhujan välillä. Näin ollen hermeneutiikasta tulee kuuntelemisen taitoa. Sitä, että kuulija ymmärtää puhujan tarkoittaman merkityksen, kuvaa hän mysteerin kaltaiseksi. Hermeneuttisen kehän muodostaa osien ja kokonaisuuden dialektinen vuorovaikutus, jonka päämääränä on saavuttaa se, mitä puhuja on todella tarkoittanut. Tälle kehälle täytyy hypätä, jotta voimme ymmärtää kokonaisuuden, ennen kuin ymmärrämme osat ja päinvastoin. Scleiermacherin merkitys hermeneutiikalle oli se, että hermeneutiikka laajeni teologiaa tai kirjallisuutta koskevaa ymmärtämisen oppia koskemaan kaikkea kielellistä ilmaisua ja sen ymmärtämistä. (Palmer 1967, 90-92.)

Wilhelm Diltheyn (1833-1911) päämääränä oli kehittää hermeneutiikasta metodi ihmistieteille (Geistesswissenschaft). Ihmistieteet voidaan ymmärtää laajasti humanistisina tieteinä, joiden kohteena on inhimillinen toiminta yhteiskuntatieteistä kasvatustieteeseen ja taidetta koskeviin oppialoihin. Metodi olisi yhtä pätevä tai jopa pätevämpi kuin luonnontieteissä vallalla olevat metodit. Dilthey tunnetaan slogaanistaan: "Luontoa me selitämme, mutta sielunelämää ymmärrämme" (Dilthey 1924). Ymmärtäminen oli Diltheyn hermeneutii- 
kan mukaan kehämäistä ja historiallista. Ymmärtämiselle ei löydy alkua tai loppua, koska ymmärtämisen prosessin kaikissa vaiheissa ymmärtäminen on suhteessa niin siihen, mitä on jo ymmärretty, kuin siihen, mitä tullaan ymmärtämään. Dilthey perustaessaan hermeneutiikkaansa otti myös käyttöön käsitteen, jolla on suuri merkitys 1900-luvun fenomenologialle, nimittäin elämyksen käsitteen Erlebnis. Sakan kielessä elämystä tarkoittava Erlebnis ja kokemusta tarkoittava Erfahrung käännetään englanniksi käsitteellä experience. Käsite Erlebnis, jotta se voitiin erottaa omaksi käsitteekseen Erfahrungista, käännettiin kahden sanan yhdistelmällä: lived experience. Kyseinen termi yleistyi myöhemmin niin fenomenologisessa kuin tutkimuksessa, joka kutsuu itseään fenomenologis-hermeneuttiseksi tutkimukseksi. Elämys on kuitenkin Diltheylle hermeneutiikkaan kuuluva käsite, joka tarkoittaa merkityksen muodostumista. Elämys on historiallinen eli aikaan sidottu, jonka vuoksi se muuttuu koko ajan. Ymmärrämme nykyistä menneen ja tulevan hermeneuttisen kehän horisontista käsin. Kokemus Erlebniksenä edustaa suoraa suhdetta elämään ja on edeltävä subjektin ja objektin erolle. (Palmer 1967,190-191.)

\section{$\mathrm{K}_{\mathrm{a}}$}

ksi kuuluisinta hermeneutiikan edustajaa, jotka kytkevät hermeneutiikan fenomenologiseen olemassaoloon ja sen ymmärtämiseen ovat Marin Heidegger ja Hans-Georg Gadamer.

Martin Heidegger sai vaikutteita hermeneutiikkaansa niin Schleirmacherilta kuin Diltheyltakin. Olemisessa ja ajassa hermeneutiikka ei tarkoita kuitenkaan tekstien tulkinnan teoriaa tai tulkintaa itseään, eikä se myöskään ole ihmistieteiden metodologiaa. Hermeneutiikka on ennen kaikkea yritys määritellä tulkinnan luonne hermeneuttiselta pohjalta. Olemisessa ja ajassa määritellään Daseinin fenomenologia hermeneutiikaksi, jolloin koko kirjaa voidaan kutsua Daseinin hermeneutiikaksi ja fenomenologiaa kyseisessä teoksessa hermeneuttiseksi fenomenologiaksi (Heidegger 2000, 61). Heideggerin tarkoitus ei ole todistaa hermeneuttisen kehän olemassaoloa, vaan ennen kaikkea osoittaa kehämäisen ymmärryksen merkitys ontologialle, olemisen ymmärtämiselle. Kehä ei ole ongelma vaan mahdollisuus ymmärtää olemista:

"Ratkaisevaa ei ole päästä kehästä ulos, vaan oikea tapa tulle kehään. Tämä ymmärtämisen kehä ei ole ympyrä, jossa mikä tahansa tietämistapa liikkuu, vaan se on itsensä täälläolon eksistentiaalisen "esirakenteen" ilmaus. ...Kehään kätkeytyy alkuperäisimmän tiedon positiivinen mahdollisuus." (Heidegger 2000, 197.)

Hermeneutiikka viittaa Daseinin olemassaolon fenomenologiseen selvitykseen ymmärtämisen ja tulkinnan ollessa Daseinin olemisen tapoja. Ymmärtäminen on voima tajuta olemisen mahdollisuus yhdessä sen maailman sisällön kanssa, jossa jokainen on, ymmärtämisen ollessa maailmassa olemisen tapa tai peruselementti. Ymmärtämisestä tulee ontologinen kysymys. Tulkinta taas ei koskaan ole edellytyksetöntä, jonkin etukäteen annetun tajuamista. Ymmärtämisessä oliot nähdään maailmassa jonakin, ja tulkinta selittää nimenomaan tätä jonakin olemista. Näin ollen hermeneutiikka ei ole pelkkä menetelmä vaan myös filosofian sisältö. Tulkitseminen perustuu kolmeen tekijään, jotka tulkitsijalla on jo hallussaan ja joihin jo on tartuttu: edellä hallussa olevaan, ennakkonäkymään ja esikäsitykseen. Näiden kolmen kautta jokin tulkitaan joksikin. Jokin on aina jotakin, eikä niin päin, että olisi ensin havainto ja sitten tulkitsisimme sen joksikin ja ymmärtäisimme. Ymmärrys ja tulkinta edellyttävät toinen toisiaan hermeneuttisen kehän tavoin. (Heidegger 2000, 196-198.)

Myöhäistuotannossaan Heidegger rinnastaa hermeneutiikka-sanan antiikin Hermes-jumalaan, joka tunnetaan jumalten viestinviejänä ja sanantuojana. Hän korostaa, että hermeneutiikka ei ole ainoastaan tulkintaa vaan ennen kaikkea sanoman kuuntelemista. Mikä tämä sanoma on, jota pitäisi kuunnella, jää tulkintojen varaan sekin. (Heidegger 1982, 29)

Heideggerin oppilas Hans-Georg Gadamer lähtee urbanisoimaan (ks Habermas 1984, 392-401) Heideggeria ymmärtäen Daseinin ihmisenä ja jättämällä Heideggerin olemisen kysymyksen pois. Gadamer määrittelee hermeneutiikan seuraavasti: "Hermeneutiikka on enemmän kuin pelkkä tieteiden metodi tai tietyn tiederyhmän erityisominaisuus. Ennen muuta se tarkoittaa ihmiselle luontaista kykyä." (Gadamer 2005, 129.) Hermeneutiikka on ihmisen luontaisena kykynä rajallista ja historiallista ja ymmärtämisestä tulee ihmisen olemisen tapa kaikenkattavana ja universaalina. Gadamerin hermeneutiikkaa ei pidä ottaa metodiopin merkityksessä, vaan todellisen kokemuksen teoriana. Gadamerin hermeneutiikan keskeisimmät aiheet ja käsitteet ovat: taideteos pelinä, hermeneuttinen kokemus ja horisonttien sulautuminen. Tässä esityksessä keskitytään ainoastaan hermeneuttiseen kokemukseen. Gadamer määrittelee kaksi käsitettä Erlebnis ja Erhfahrung, joista jälkimmäi- 
nen viittaa hermeneuttiseen kokemukseen:

"Ensinnäkin elämys, joka vahvistaa ja täyttää meidän odotuksemme, ja toiseksi kokemus, joka 'tapahtuu' meille. Tämä jälkimmäinen, kokemus aidossa mielessä, on aina negatiivinen. Kun uusi kokemus kohteesta tapahtuu meille, se tarkoittaa, että emme aiemmin ole nähneet kohdetta oikein ja nyt tiedämme paremmin." (Gadamer 1965, 335336.)

Hermeneuttinen kokemus on aina tekemisissä tradition kanssa. Traditio ja historiallinen tietoisuus muodostavat yhdessä korkeimman hermeneuttisen kokemuksen muodon, jota Gadamer kutsuu avoimuudeksi traditiolle (Huttunen 2007). Gadamerin hermeneutiikan ero perinteisestä romanttisesta hermeneutiikasta löytyy hänen ymmärtämisen määrittelystä: "Ymmärtäminen ei tosiasiassa ole paremmin ymmärtämistä ... Riittää, että sanomme ymmärtävämme toisella tavalla, jos ylipäätään ymmärrämme.”'(Gadamer 1965, 280.)

Ero perinteiseen hermeneutiikkaan näkyy erityisesti Gadamerin hermeneuttisen kehän käsitteessä. Hermeneuttiseen kehään kuuluu esiymmärrys ja horisontti, ennakkoluulo ja traditio. Gadamer ei näe hermeneuttista kehää suljettuna kehänä, vaan mennyt ymmärretään aina suhteessa nykyiseen. Ymmärtäminen ei ole koskaan täydellistä eikä totuus absoluuttista, koska ihmisen olemassaolo on historiallista ja rajallista. Ihmisellä on aina tietty aika ja paikka sekä traditioon liittyvä esiymmärrys, jotka muodostavat horisontin, josta käsin ihminen tulkitsee ja ymmärtää maailmaa. Traditio on kahdessa merkityksessä hermeneuttisessa kehässä. On traditio, jota tulkitaan ja toisaalta on traditio, josta tulkitaan, ja tulkinta yhdistää nämä kaksi tuoden esiin jotain aivan uutta. (Koski 1995, 101-102.)

Hermeneuttinen kehä ei ole metodi, vaan kaiken ymmärtämisen välttämätön perusta. Samoin hermeneuttinen kokemuskaan ei ole metodi vaan toisenlaisen totuuden ja tiedon kokemus. Hermeneuttinen kokemus on ennen kaikkea tapahtuma. Hermeneuttisessa kokemuksessa jotakin tapahtuu tulkitsijalle itselleen. Siinä asiat paljastuvat erilaisina tai kokonaan uusina ennakkokäsityksiimme eli ennakkoluuloihimme verrattuna ja kokemusta voidaan kutsua negatiiviseksi. Kokemus saa kokijan kysymään maailmaansa ja itseään uudella tavalla. Kun jokin paljastuu maailmassa hermeneuttisen kokemuksen ansiosta, muuttaa se meidän horisonttiamme ja ymmärrystämme laajentaen tai pienentäen tai tehden kumpaakin. Gadamerin her- meneutiikkaan liittyvä totuus on näin dynaaminen ja historiallinen, ei staattinen eikä ikuisia totuuksia kantava eikä niitä kohti kulkeva. Ymmärryksemme voi kyllä laajeta ja laadullisesti muuttua, mutta kuten Gadamer kuuluisassa sloganissaan toteaa: "Oleminen, jota voidaan ymmärtää, on kieltä" (Gadamer 1976, 31 ja 102; 1989, 747.) Emme näin ollen voi koskaan ymmärtää kaikkea.

Hermeneutiikka ei suinkaan pääty tähän, vaan voin mainita esimerkiksi Paul Ricouerin, joka liittää narratiivisen itseyden hermeneutiikkaan (Huttunen ja Kakkori 2002). On myös muita useita filosofeja ja ajattelijoita, joilla on paljonkin annettavaa hermeneutiikalle, kuten Karl-Otto Apel, Emilio Betti, Rudolf Bultman, Jürgen Habermas, Gianni Vattimo. Heidät on valitettavasti jätettävä vain maininnalle.

\section{Hermeneutiikan ja fenomenologian yhdistyminen van Manenilla}

Erityisesti saksankielisellä alueella fenomenologiaa on kehitetty kasvatustieteen alalla metodiksi tutkia ja harjoittaa kasvatustieteitä. Mainittakoon Alois Fisher, Rudolf Lochner, Käte MeyerDrawe., Wilfried Lippitz, Wolfgang Sünkel, Klaudia Schultheis ja Klaus Prange. Fisher ja Lochner kehittivät deskriptiivisen pedagogiikan koulukunnan Husserlin fenomenologina pohjalta. Fisherin pyrkimyksenä oli konstruoida kasvatukselle ehdoton perusta ja kuvaus puhtaasta kasvatustilanteesta. Deskriptiivinen pedagogiikka erosi kuitenkin nopeasti husserlilaisesta fenomenologiasta ja kehittyi Lochnerin toimesta positivististisen kasvatustieteen suuntaan (Siljander 1991, 1). Husserlilaisen fenomenologian soveltaminen suoraan kasvatuksen tutkimukseen johti ideaan puhtaasta kasvatustodellisuudesta, joka on kaukana hermeneutiikan pyrkimyksistä. Hermeneuttis-fenomenologista tutkimusmetodin esiintuojana ja kehittäjänä tunnetaan mainitsemani van Manen niin pohjoismaissa kuin Kanadassakin.

Kirjassaan Researching Lived Experience van Manen kutsuu hermeneuttis-fenomenologiseksi lähestymistavaksi kehittämäänsä ihmistieteiden tutkimusmetodiaan. Hän määrittelee hermeneuttisfenomenologien tutkimusotteen perustuvan filosofiaan, jolloin on tiedettävä jotakin filosofian perinteestä. Hän kuitenkin painottaa, ettei jokaisen kasvatustieteilijän tarvitse tulla professionaaliseksi filosofiksi, jotta vois käyttää metodia. Hänen mukaansa on riittävää, että tietää hermeneutiikan ja 
fenomenologian epistemelogiset tai teoreettiset implikaatiot. (van Manen 1990, 8-9.)

Kirjassaan van Manen tarjoaa hedelmällisen kuvauksen hermeneuttis-fenomenologisesta reflektiosta ja kirjoittamisesta. Kuitenkin tiettyjä teoreettisia ongelmia ja ristiriitoja jää hänen argumentaatioonsa hermeneutiikasta ja fenomenologiasta. Hän käyttää laveasti koko fenomenologian perinnettä tekemättä minkäänlaista erottelua tai analyysia erilaisten fenomenologioiden tai hermeneutiikan suuntausten välille. Yhdeksi ongelmaksi nousee hänen tulkintansa Husserlin elämismaailmakäsitteestä. Van Manen väittää, että elämismaailma on luonnollisen asenteen jokapäiväinen maailma (van Manen 1990, 7). Tässä tulkinnassa luonnollinen asenne ja elämismaailma samaistetaan virheellisesti, koska juuri luonnollinen asenne oli se, joka husserlilaisessa fenomenologiassa sulkeistettiin ja josta piti toisin sanoen päästä eroon reduktiolla. Käsite on keskeinen van Manenille. Käsite on kytköksissä myös Diltheyn Erlebniseli elämys-käsitteeseen ja tämä tuo esiin toisen ongelman. Gadamerilaisessa hermeneutiikassa kokemus on vastakkainen käsite elämykselle, kokemuksen viitatessa hermeneuttiseen kokemukseen. Heideggerille Erlebnis, elämys edustaa vaihetta, jossa taide voi kuolla, kokemuksen edustaessa Ehrfahrungina pääsyä niin taiteen kuin kielenkin ymmärtämiseen (Heidegger 1995, 83).

Van Manenilta löytyy myös toinen ongelma hänen yhdistäessä hermeneutiikan ja fenomenologian. Hän mukaansa hermeneuttis-fenomenologinen tutkimusotteen tehtävänä on paljastaa olemuksia. Traditionaalinen fenomenologia näki tehtäväkseen päästä käsiksi kokemuksen olemukseen. Van Manenin mukaan olemuksen merkitys ja ilmiön olemus ovat sama asia (van Manen 1990, 78). Kirjan alussa hän on samaa mieltä niin Husserlin kuin Merleau-Pontyn kanssa siitä, että ilmiön olemus on jotain universaalia, eli olemus on se, joka tekee jostakin sen mitä se on (van Manen 1990, 10). Moderni hermeneutiikka ei kuitenkaan tunnista tai edes pyri tunnistamaan universaalia olemusta. Hermeneutiikan tehtävänä on ymmärtäminen ja tulkinta maailmassa ja se, miten eri tavalla olemisemme maailmassa on yhteydessä ymmärtämiseen. Myöhemmin van Manen näyttää muuttavan mieltään tässä kohdin kirjoittaen: 'Käsite olemus voidaan ymmärtää kielellisenä konstruktiona, ilmiön kuvauksena." (van Manen 1990, 39.) Asia jää kuitenkin epäselväksi. Mutta van Manen näyttäisi tulevan lähemmäksi narratiivista ja konstruktiivis- ta ajattelua kuin perinteistä fenomenologiaa.

Voi olla, että olen lukenut van Manenia ilman hermeneuttista suopeutta. Hänelle on annettava kiitos siitä, että hän tuo omalla tavallaan esiin niin sanotun hermeneuttis-fenomenologien tutkimusotteen tärkeät ongelmat. Van Manen on luonut erittäin käyttökelpoisen mallin laadullisen aineiston analyysiin. Tämä malli on suhteellisen irrallinen van Manenin luomasta hermeneutiikan ja fenomenologian synteesistä, joka filosofisen teorian tasolla epäonnistuu. Kysymykseni onkin se, miksi ei riitä tehdä joko fenomenologista tai hermeneuttista tutkimusta tai esimerkiksi narratiivista tutkimusta.

On selvää ja kiistatonta, että fenomenologialla ja hermeneutiikalla on annettavaa toisilleen ja erityisesti ihmistieteille, mutta väitteeni on kuitenkin, että niillä on perustavanlaatuisia eroja. Fenomenologinen metodi ei muutu hermeneuttis-fenomenologiseksi vain siksi. että ymmärrämme ja tulkitsemme asioita.

En ole ottanut yhtä isoa kysymystä esiin, nimittäin totuutta. Kysymys totuudesta kytkeytyy käsitykseen olemuksesta, ja hermeneutiikalla ja fenomenologialla on erilainen totuuskäsitys. Haluan vielä painottaa, että niin fenomenologialla kuin hermeneutiikalla on paljon annettavaa tutkimukselle ja jos käyttää näiden yhdistelmää, on näiden kahden välinen jännite tunnistettava, jotta tutkimuksen taso säilyisi ja kehittyisi eteenpäin.

\section{Lähteet}

Carr, D. (1981). Translator's Introduction in: E. Husserl The Crisis of European Sciences. An Introduction to Phenomenological Philosophy. Evanston: Northwestern University Press.

Dilthey, W. (1924). Ideen über eine beschreibende und zergliedernde Psychologie [1894]. In: W. Dilthey Gesammelte Werke Bd. 5. Leipzig, Berlin: Teubner, S. 139-240

Encyclopædia Britannica (2007). Encyclopeadia Britannica Online. 31 Aug. $2007<\mathrm{http} / /$ www.britannica.com/eb/article-68551>.

Derrida, J. (2008). Johdanto. in E. Husserl: Geometrian alkuperä. [Die Frage nach dem Ursprung der Geometrie als intentional-historisches Problem]. Tampere: niin\&näin -lehden filosofinen julkaisusarja. 
Gadamer, H.-G. (1965). Wahrheit und Methode. Grundzüge einer philosophischen Hermeneutik. 2. Auflage. J.C.B. Mohr, Tübingen

Gadamer, H.-G. (1976). Philosophical Hermeneutics. Los Angeles; University of California Press.

Giorgi, A. (1985). Phenomenology and psychological research. Pittsburgh, PA: Duquesne University Press.

Gadamer, H.-G. (1988). Truth and Method. New York: Continuum.

Gadamer, H.-G (2005). Hermeneutiikka. Tampere: Vastapain.

Habermas, J. (1984). Philosophisch-poltische Profile. Frankfurt am Main: Suhrkamp Verlag.

Hegel, Georg Wilhelm Friedrich (1998). Phänomenologie des Geistes. Berlin: Akademie Verlag.

Heidegger, M. (2002). Off the Beaten Track. Cambridge: Cambridge University Press.

Heidegger, M. (1982). On the Way to language. San Francisco: Harper.

Heidegger, M. (1975). Die Grundprobleme der Phänomenologie. Gesamtausgabe Band 24. Frankfurt am Main: Vittorio Klostermann.

Heidegger, M. (2000). Oleminen ja aika. Tampere: Vastapaino.

Husserl, E. (1965). Phenomenology and the Crisis of Philosophy. Philosophy als Rigorous Science and Philosophy and the Crisis of European Man. New York: Harper \& Row.

Husserl, E. (1969). Die Krisis der europäischen Wissenschaften und die transzendentale Phänomenologie : eine Einleitung in die phänomenologische Philosophie. Haag: von Walter Biemel.

Husserl, E. (1992). Ideen zu einer reinen Phänomenologie und phänomenologischen Philosophie. Hamburg: Meiner.

Husserl, E. (1999). Cartesian Meditations. Hague: Martinus Nijhoff.

Huttunen, R. (2007). Gadamer-Habermas -debatti. http://filosofia.fi/node/2833. 11.3.2008.

Huttunen, R., Kakkori, L. (2002). The hermeneutics of truth and selfhood - Heidegger's, Gadamer's, and Ricouer's - Significanse in the autobipgraphical research, in R.Huttunen,

H. Heikkinen and L. Syrjälä (eds.) Narrative Re- search. Voices of teachers and philosophers. Jyväskylä: Sophi.

Juntunen, M. (1986) Edmund Husserlin filosofia. Mänttä: Gaudeamus.

Koski, J. T. (1995) Horisonttiensulautumisia : keskustelua Hans-Georg Gadamerin kanssa hermeneutiikasta, kasvamisesta, tietämisestä ja kasvatustieteestä. Helsinki: Helsingin yliopiston opettajankoulutuslaitos.

van Manen, M. (1984) Practicing phenomenological writing. Phenomenology + pedagogy, 2 (84). 36-39.

van Manen, M. (1989) Phenomenology + pedagogy, 7(89), 232-253.

van Manen, M. (1990) Researching lived Experience. Human science for an action sensitive pedagogy. New York: Sate University of New York Press.

Merleau-Ponty, M. (2006) Phenomenology of Perception. London: Routledge.

Palmer, R. E. (1969). Hermeneutics. Interpretation Theory in Schleiermacher, Dilthey, Heidegger, and Gadamer. Evanston: Northwestern University Press.

Natason, M. (1973). Edmund Husseerl. Philosopher of Infinite Tasks. Evanston: Northwestern University Press.

Polkinghorne, D. E. (1976). An existentialphenomenological approach to education. San Francisco: Freeperson.

Spiegelberg, H. (1984). The phenomenological Movement. A historical introduction. Hague: Martinus Nijhoff Publishers.

Siljander, P. (1991). Empiirisen kasvatustieteen perusteita : klassinen eksperimentaalinen pedagogiikka, deskriptiivinen pedagogiik$k a$, empiiris-analyyttinen kasvatustiede, Foundations of empirical education : classical experimental pedagogy, descriptive pedagogy, empiro-analytical education. Oulu: $\mathrm{Ou}-$ lun yliopisto.

Zahavi, D. (2003). Husserl's Phenomenology. Stanford University Press.

\section{IImestynyttä}

Leena Kakkori (2009). Martin Heideggerin olemisen kysyminen. Tampere University Press. 207 sivua. 